XX. Contributions to the Knowledge of the Foraminifera.-On the Rhizopodal Fauna of the Shetlands. By Henry B. Brady, F.L.S.

(Plate XLVIII.)

Read February 18th, 1864.

BUT little addition has been made to our knowledge of the British marine Rhizopodal fauna since the publication by the Ray Society in 1858 of Professor Williamson's Monograph on the Recent Foraminifera of Great Britain. This careful and excellent work must be looked upon as the starting-point of systematic labour on the subject, rather than as an exhaustive history of the organisms of which it treats. In it there are collected together many of the fragmentary notices of Foraminifera which occur in the works of the earlier British naturalists, with collateral references to the writings of Continental authors but little known here. An effort is conspicuous throughout the volume towards a reduction of the number of species and genera, so large a proportion of which had previously been determined on trivial and unimportant characters; and the groundwork of our knowledge of their distribution in our seas is laid in the careful list of localities appended to the description of each species. The beautiful plates with which the work is illustrated were the first series published in this country of any value to the working naturalist, and are of great practical use as a standard of reference.

Further research, with the advantage of such a groundwork, naturally yields rapid additions to our store of facts. The examination of sands from depths not before dredged, or localities not previously visited, brings to light species new to our coast, and shows the wider distribution of those already known.

Since the publication of the 'Monograph' the nomenclature of the entire group has undergone considerable change, due to its laborious revision by Messrs. Parker and Jones ; and Dr. Carpenter's ' Introduction to the Study of the Foraminifera,' written with the concurrence and assistance of the before-named naturalists, has unfolded a system of classification which, though involving many difficulties, is the only one hitherto proposed possessing a natural and at the same time an obviously scientific basis. Thus it will be seen that the facilities for the study of these organisms are now very different from those which existed a few years ago, and the altered state of our knowledge of the Protozoa generally will explain many points in which the course of the following paper differs from that pursued in Professor Williamson's work.

During the past few years I have had the opportunity, through the kindness of several naturalist friends, of examining large quantities of material from various portions of our coast, both littoral sands and those dredged from deep water, with respect to the microzoa contained in them; and I propose in the present paper to give the results of a careful investigation of a series of dredgings obtained from the Shetland Islands in the summers 
of 1861 and 1863 by Mr. J. Gwyn Jeffreys and Mr. E. Waller, and very kindly placed at my disposal by them.

Those who are in the habit of referring to Professor Williamson's Monograph, before alluded to, must have remarked how large a proportion of the rarer British species of Foraminifera have been collected on this ground. Of the species therein described, the occurrence of seventy-six is considered of sufficient interest to have a list of localities appended, and in fifty-seven of these cases Shetland appears, either alone or in company with other places. The researches of the late Mr. Barlee in past years and of Mr. Jeffreys are the basis upon which this record is founded; but, notwithstanding their labours, the same ground amply repays further study.

It has been remarked that, in many departments of natural history the fauna of the north and north-east shores of Great Britain is of a boreal character, and presents stronger affinities to that of the coast of Norway than of the south coast of England. The results of the recent dredging-operations off Northumberland and Durham suggested the observation; and, as might be expected, the facts now brought forward yield additional evidence of its correctness. The occurrence of Anomalina coronata, Lagena distoma, and Glandulina lavigata, all of them prominent forms on the Norwegian coast, is exceedingly interesting viewed in this light, and there remain but two or three of the species described in Messrs. Parker and Jones's memoir on Norwegian Foraminifera (Ann. \& Mag. Nat. Hist. 2nd ser. vol. xix. p. 273, \&c.) which have not been found in the Shetland Seas. The supposed occurrence of certain tropical or subtropical forms, to which I shall presently refer, has been accounted for on the supposition that chance specimens had been carried into these regions by the Gulf-stream. I have sought in vain for any evidence of the influence of the great ocean-current in the Rhizopodal fauna of our northernmost shores; indeed it seems pretty well established that on the eastern side of the Shetlands, at any rate, the distribution of animal life is not affected by it. The Foraminifera obtained fully confirm the views expressed by Mr. Jeffreys in the introduction to his ' British Conchology,' that whatever matter of foreign origin is washed upon these shores is derived from the opposite Norwegian coast.

Most of the parcels of sand placed in my hands were carefully labelled as to the depth from which they were obtained, and the appended Table will give a general view of the results of their examination. The arrangement of the Table and its classification are based upon the views advocated in Dr. Carpenter's work; and the easy way in which the various members of the group fall into their places when treated with reference to this system suggests the applicability of the term "natural" to it, in contradistinction to the "artificial" methods of d'Orbigny, Schultze, and others, founded on the mere number of chambers making up the shell, or their degree of development. The nomenclature has been adopted to a great extent from the Appendix to the same book, with a few trifling corrections, and some alteration in the use of specific and varietal terms. It would be out of place here to enter upon the much-vexed question of what constitutes a species, especially as all allow that in the Protozoa a much larger range of variation must be allowed within specific limits than it is usual to grant in more highly organized beings. Usually the species of a genus (sometimes of several so-called genera) are assignable to 
one central typical form; the more extensive the series of specimens examined, the more closely connected the links of the chain which binds the whole series, and very frequently it is impossible to say with certainty under what particular name specimens of the intermediate forms should stand. At the same time these subspecific and varietal distinctions are of considerable importance to the zoologist and the geologist as indicating the existence of certain climatal and bathymetrical conditions, and are in practice equally necessary whether representing true species or not. The varietal forms are sufficiently recognizable and sufficiently characteristic of habitat to deserve binomial appellation, and, so long as the connexion is understood, it is unnecessary to overload the terminology by constant repetition of the specific name as well. Whilst preserving, therefore, the specific names hitherto adopted, they have been arranged under their respective types in order to preserve the connexion indicated. Subvarietal names have only been employed in a few cases in which no author has thought the distinction sufficient to merit specific appellation. The names used in Professor Williamson's Monograph have been given in a parallel column, together with reference to his figure of each form.

Of the species figured by Professor Williamson only ten will be missed in the Table of the Shetland forms, and it seems probable that one or two, at least, of these have been introduced on the authority of chance fossil specimens washed out of the strata on the sea-coast. Such errors are frequent in the works of Walker and Boys, and some other conchologists, and are corrected with difficulty. The two species of Frondicularia figured in the Monograph (pl. 2. figs. 50 \& 51), from specimens found at Sandwich, have probably been derived in this way from the chalk cliffs of Kent. Many species of the genus are common in the chalk, and amongst them the particular forms alluded to, but are almost unknown in a recent state in the seas of temperate regions. In the same way Cristellaria subarcuatula, var. costata, pl.2. fig. 63 (Marginulina raphanus, d'Orb.), and C. subarcuatula, var. costata, pl. 2. figs. 64 \& 67 (Planularia strigilata, Reuss), are probably derived, the former from the Tertiary beds near Sandwich, the latter from the Oxford or the Kimmeridge clay of Dorsetshire. With reference to another species, Peneroplis planatus, one or two specimens of which were supposed to have been found in Shetland sand, I have the following memorandum from Mr. Jeffreys, which renders it necessary to exclude it from the British list; and as Vertebralina striata was found in the same parcel, it must share the same fate. Mr. Jeffreys writes :- "I have reason to believe that the admission of Peneroplis planatus into the list of British Foraminifera was accidental and erroneous, so far as I was concerned. Soon after my return from a scientific excursion to the coast of Piedmont, Mr. Barlee sent me some shell-sand which he had dredged in Shetland, and I used for the separation and examination of the same sieves that I had with me in Italy. Although these sieves had been carefully washed and cleaned before I left Genoa, a few remnants of my Mediterranean dredgings may have been left in the folds of the wire-work within the rim, and hence the mixture of Southern and Northern productions." Peneroplis is common in the Mediterranean, as is also Vertebralina; and as this is the only recorded instance of their occurrence in so high a latitude, it has probably come about accidentally as above suggested.

In completing the list of Shetland Foraminifera, I have inserted the names of four or 
five forms which I have not myself noticed, on the authority of Mr. Barlee's specimens noted in Professor Williamson's work, and in the few instances in which this has been done it is duly acknowledged.

I have to thank my friends Messrs. Parker and Jones for their kind assistance in many doubtful points-assistance they have been ever ready to render, and doubly valuable from their great experience and extensive knowledge of all matters connected with the Protozoa.

Notes on the rarer Species and Varieties obtained-chiefly on those not before recorded as British.

[The numbers refer to the corresponding numbers in the annexed list.]

No. 5. Brloculina sphera, d'Orb. (Plate XLVIII. fig. 1.)

Two specimens of this rare and interesting Biloculina were found. In its fully developed condition it is sufficiently distinguished from its allies by its spherical shape and the large, rounded outer chamber, which almost entirely embraces the inner ones. It is described by d'Orbigny in the 'Voyage dans l'Amérique méridionale;' but his figures (pl. 8. figs. 13-16) are defective, and do not show the aperture. Mr. Parker has several specimens from the Butt of Lewis. Diameter $\frac{1}{40}$ inch.

No. 6. Biloculina contraria, d'Orb. (Plate XLVIII. fig. 2.)

A large, coarse shell, differing from the other varieties of the same type in the form and disposition of the chambers, which are here found in a directly opposite condition to that usually observed in the Biloculince. The whole shell is compressed laterally instead of from front to back, and the position of the aperture is correspondingly altered, being situated near the summit of the narrow, rounded end-view, so to speak, of the shell. It appears to be exceedingly rare, only two specimens having occurred in the examination of a large quantity of material. Diameter $\frac{1}{18}$ inch. (See d'Orb. For. Foss. Bas. Tert. Vien. p.:266, pl. 16. figs. 4-6.)

No. 12. Triloculina tricarinata, d'Orb. (Plate XLVIII. fig. 3.)

This is a tolerably well-defined modification of the Triloculine subtype, characterized by having each of the three external chambers extended to a sharp edge, thus forming three keels or ridges running from end to end of the shell. It is a common form in many seas, and occurs abundantly in a fossil condition in the Tertiaries of Grignon and other deposits. Long diameter $\frac{1}{32}$ inch. (See d'Orbigny's 'Modèle' no. 94.)

No. 17. Quinqueloculina PUlchella, d’Orb. (Plate XLVIII. fig. 4.)

In reduring the numberless species of Triloculina and Quinqueloculina founded by d'Orbigny and others upon the mere surface-ornamentation of the chambers, it will be found convenient to keep this name, applied to one of Soldani's figures (adopted by d'Orbigny, Ann. des Sci. Nat. vol. vii. p. 303), for the forms characterized by coarse longitudinal ridges. In the same way, Quinqueloculina Brongniartiana should take pre- 
cedence as the varietal term for those marked by delicate striæ. The distinction between Triloculina and Quinqueloculina is a purely artificial one; probably the only forms persistently showing three external chambers are Triloculina trigonula and $T$. tricarinata. The single specimen found in these dredgings assignable to $Q$. pulchella is a somewhat monstrous one, the outermost chamber having deep lateral constrictions, apparently dividing it into several segments. Long diameter $\frac{1}{15}$ inch.

No. 19. Trochammina infuata, Montagu, sp.

Rotalina inflata, Will.

A few young specimens, obtained by Professor Williamson from Shetland sands communicated by Mr. Barlee. (See Will. Rec. For. Gt. Brit. p. 50, pl. 4. figs. 93 \& 94.)

No. 20. Lituora scorpiurus, Montfort, sp. (Plate XLVIII. fig. 5.)

This is a feeble form of Lituola, having the characteristic rough, arenaceous test; the chambers are arranged in a straight line instead of spirally as in the type L. nautiloidea. Professor Williamson figures in his first plate what may possibly be a single chamber of this shell, but many perfect specimens have occurred both to Mr. Waller and myself. Length $\frac{1}{12}$ inch. (See Ann. \& Mag. Nat. Hist. 3rd ser. vol. vi. p. 346.)

No. 31. Lagena caudata, d'Orb., sp.

Entosolenia globosa, var. lineata, Will.

Found in this locality by Mr. Barlee. (See Will. Rec. For. Gt. Brit. p. 9, pl. 1. fig. 17.)

No. 32. Lagena distoma, P. \& J., MS. (Plate XIVIII. fig. 6.)

A beautifully delicate elongate variety of Lagena sulcata, W.\& J., having an aperture at each end of the shell. It has a long fusiform shape, two equal and symmetrical ends, and a surface-ornamentation of delicate longitudinal lines. It was described and figured by Messrs. Parker and Jones (who have since named it $L$. distoma) in their paper on the Foraminifera of the Coast of Norway (Ann. \& Mag. Nat. Hist. 2nd ser. vol. xix. pl. 11. fig. 24). Only one specimen has been found in the Shetland dredgings, but several have been taken in sand dredged on the coast of Northumberland. It occurs in a subfossil condition in the clay of the Fens near Peterborough. Length $\frac{1}{60}$ inch, breadth $\frac{1}{350}$ inch*.

* Since writing the above, I have received a copy of a Memoir by Professor Seguenza ('Dei Terreni Terziarii del Distretto di Messina e dei Foraminiferi Monotalamici delle Marne Mioceniche Messinesi,' scritta da Giuseppe Seguenza : Messina, 1862) containing figures and descriptions of a considerable number of what seem to be distomatous Lagence. In this work, the forms of Lagena which are produced at both extremities sufficiently to assume a more or less fusiform character are included under a separate genus, Amphorina, d'Orb., and the author does not appear to have noticed that in many, if not in most instances, shells in this condition have two apertures, as is easily seen in recent specimens. All the varieties of Lagena are liable to assume the peculiarity alluded to, and do so frequently in a manner which does not admit of the assumption that it is either a generic or even a specific character on the one hand, or a mere monstrosity on the other. The form described in the text has been thought by Messrs. Parker and Jones worthy of subspecific name, there not being, so far as is known, any precise analogue to it in the single-apertured series. 
No. 41. Lingulina carinata, d'Orb.

No specimen has rewarded my diligent search for it. Mr. Barlee's better fortune (see Will. Rec. For. Gt. Brit. p. 14) entitles us to retain it in our list,-a point of interest, for the reasons before stated, in connexion with the Norwegian fauna.

No. 42. Glandulina læivigata, d'Orb. (Plate XLVIII. fig. 7.)

Mr. Waller, in his search for the shells of the Mollusca, has been fortunate enough to meet with four specimens of this beautiful species. It is common in a fossil state in many strata, but the individuals are usually smaller than those found in a recent con. dition. It has considerable geographical range, being noted as far north as the Norwegian coast, but does not seem to be abundant in a living state anywhere. G. lavigata is pretty well known by d'Orbigny's figures (Ann. des Sci. Nat. vol. vii. pl. 10. figs. 1-3, and For. Foss. Bas. Tert. Vien. pl. 1. figs. $4 \& 5$ ), and may be looked upon as a subtype of Nodosaria. Length $\frac{1}{30}$ inch.

No. 57. Bigenerina digitata, d'Orb. (Plate XLVIII. fig. 8.)

Though Bigenerina can scarcely be said to represent a true genus, it is a convenient term for a tolerably well-defined group of Textularia. Its peculiar mode of growth, commencing biserially like the typical Textularia, but becoming uniserial after a certain number of chambers are formed, is sufficient to distinguish the group from its allies. Like the larger Textularia, its shell is arenaceous in texture, and the arrangement of the chambers is often obscured by its rough exterior. The specimens collected are less attenuated than d'Orbigny's 'Modèle' no. 58, but the earlier chambers have not the wider growth which gives the spear-headed contour to his other species, B. nodosaria. It occurs sparingly in several parcels of dredgings from depths of 70 to 90 fathoms. Length $\frac{1}{20}$ inch.

No. 66. Bourvina punctata, d'Orb. (Plate XLVIII. fig. 9.)

Typically, Bolivina punctata belongs to a triserial group, Bulimina; but in the enfeebled form in which it is found in Northern seas it becomes biserial, and is isomorphous with Textularia, from which it is with difficulty distinguished. The twisted mode of growth and oblique aperture, as figured by d'Orbigny (Voyage dans l'Amér. mérid. pl. 8. figs. 10-12), are tolerably characteristic, but these are by no means invariable features in the exceedingly small and delicate specimens found in the Shetland dredgings. Length $\frac{1}{75}$ inch.

No. 70. Discorbina ochracea, Will., sp.

Obtained from Mr. Barlee's Shetland sands. (See Will. Rec. For. Gt. Brit. p. 55, pl. 4. fig. 112, \& pl. 5. fig. 113.) 
No. 72. Discorbina Ber'rheloti, d'Orb., sp. (Plate XLVIII. fig. 10.)

Rosalina Bertheloti*, d'Orb. For. des îles Canaries, pl. 1. figs. 28-30.

A delicate flattened variety of Discorbina turbo, d'Orb., sp., having the central chambers depressed so as to form a sort of umbilical disk. Viewed from underneath, the chambers are seen to overlap each other successively, the smaller in front of the larger, and the aperture is hidden by the spreading growth of the large terminal chamber. Each chamber has a slightly marked border, and the whole shell is covered with minute inconspicuous perforations. Diameter $\frac{1}{100}$ inch.

No. 74. Planorbulina Haidingeril, d'Orb., sp. (Plate XLVIII. fig. 11.)

The artificial system of classification adopted by d'Orbigny with reference to the Foraminifera is never more at fault than when dealing with the numerous varieties of Planorbulina, Discorbina, \&c., which he has grouped together in the genus Rotalia. Most of his species are quite worthless, some of them not even representing varietal distinctions of sufficient permanence to notice. In rearranging this motley assemblage of forms, Messrs. Parker and Jones propose to keep Planorbulina farcta (Fichtel and Moll, sp.) as the type of a genus; and if this name is confined to the bold large-pored form growing attached, $P$. Haidingerii becomes a convenient subspecific term for the round-edged form growing free, and $P$. Ungeriana is applicable to the unattached, feebler, thin-edged varieties.

A considerable number of specimens of $P$. Haidingerii have been found in these sands, of average size, though not so bold and thick in contour as they occur in warmer seas and in some tertiary deposits, but resembling more d'Orbigny's figure of Rotalia Akneriana, one of the subvarietal forms included under $P$. Haidingerii. Diameter $\frac{1}{30}$ inch. (See For. Foss. Bas. Tert. Vien. pl. 8. figs. 7-9, 13-15, \&c.)

No. 75. Planorbulina Ungeriana, d'Orb., sp. (Plate XLVIII. fig. 12.)

A small Planorbulina growing unattached, more delicate than the last-named species. It has a deep central umbilicus, and the chambers are extended at their outer edge into a sharp keel, giving the appearance of a narrow border running round the shell. Diameter $\frac{1}{35}$ inch. (See For. Foss. Bas. Tert. Vien. pl. 8. figs. 16-18, \&c.)

No. 77. Anomalina cononata, P. \& J. (Plate XLVIII. fig. 13.)

My attention was first drawn to this shell in the Shetland dredgings by Mr. Waller, and $I$ have since found it in considerable quantity in the material brought home by Mr. Jeffreys last year, taken from a depth of 85 and 90 fathoms. It may be described as a subsymmetrical biconcave Planorbulina growing unattached. It seems to be common at all depths on the Norwegian coast, and is plentiful in the Mediterranean

* This species has the name of Rosalina Bertheloti in the text, whilst $R$. Berthelotiana appears on the plate-a sort of oversight not uncommon in d'Orbigny's works. As it seems probable that the author would append to his description of the species the aame he intended it to bear, the former has been adopted. The same course has been pursued with reference to Nonionina stelligera, the last-named species on my list, which is called $N$. stellifera on d'Orbigny's plate.

VOL. XXIV. 
at a depth of 90 fathoms. A few very fine specimens have been found in the Tertiaries of Grignon, but its occurrence in a fossil condition elsewhere has not been noticed. Diameter $\frac{1}{20}$ inch. (See Ann. \& Mag. Nat. Hist. 2nd ser. vol. xix. p. 294, pl. 10. figs. 15 \& 16.)

No. 80. Pulvinulina concentrica, P. \& J., MS. (Plate XLVIII. fig. 14.)

A variety of $P$. repanda, F. \& M., sp., distinguished by the broad striking bands of clear shell-substance overgrowing the septal lines. It is not by any means abundant, and, except in two or three instances, the specimens are small. It seems to be common in the Mediterranean, where it attains great size and beauty, and it also occurs in the Bay of Biscay. Diameter $\frac{1}{20}$ inch. (See Soldani, Testac. pl. 37. fig. B.)

No. 81. Pulvinulina Karstent, Reuss, sp. (Plate XLVIII. fig. 15.)

Three or four small starved specimens of this species have been pointed out amongst my mountings by Mr. Parker. It is almost impossible to distinguish it, in the arrested condition here presented, from srnall specimens of its isomorph Discorbina rosacea, except by a comparison of a large series of examples, although when fully developed the two forms have striking peculiarities. As I have never met with mature specimens, I can only refer to Professor Reuss's memoir on the Chalk of Mecklenburg (Zeitschr. Deutsch. Geol. Gesellsch. vol. vii. p. 273, pl. 9. fig. 6), and in this instance I have preferred copying his figures of the shell to drawing direct from immature specimens. Diameter $\frac{1}{40}$ inch.

No. 84. Rotalia orbicularis, d'Orb. (Plate XLVIII. fig. 16.)

Although this form was considered by d'Orbigny sufficiently distinct to merit a subgeneric name (Gyroidina), we cannot regard it as more than a deep-sea variety of Rotalia Beccarii. It is a thickened, Rotaline form, presenting in profile a trochoid appearance, rising to a point on the upper, and very convex on the lower surface. The septal face is narrow and shows few or no perforations. A few specimens have been found in soundings from the Irish Sea (off Laxey), but it is rare, and the individuals exceedingly small both from this and the Shetland locality. The species is common in deep water in the Red Sea and in the Mediterranean. Diameter $\frac{1}{100}$ inch. (D'Orbigny's 'Modèle' no. 13.)

No. 85. Trnoponus Levis, P. \& J. (Plate XLVIII. fig. 17.)

The specimen of this shell represented in the figure is the only one which I have seen from a British locality. It is nearly globular and a good deal worn, and might easily in this condition be mistaken for a large grain of sand; a little observation, however, shows on its surface the obscure and more or less hexagonal markings caused by the prominence of the septal edges. The specimen is exceedingly small when compared with those of tropical origin, being not more than $\frac{1}{30}$ inch in diameter.

All the species of the genus Tinoporus are found in greater abundance in the seas of warm than in those of colder regions, though the small spherical variety now under notice has a wider geographical range than the larger forms which exist in such abundance amongst the coral-reefs of Polynesia. Mr. Parker notes the occurrence of T. lavis 
at Arran, and the single example from Shetland extends its geographical limit still further northwards.

No. 86. Patellina corrugata, Will.

Observed by Mr. George Barlee. (See Rec. For. Gt. Brit. p. 47.)

No. 90. Polystomella arctica, P. \& J., MS. (Plate XLVIII. fig. 18.)

A large, thick-walled Polystomella found in Northern seas. The shell is smooth and devoid of the ridges and spinous processes usually found in the typical form, P.crispa. The apertures are scarcely visible, owing to the excessive development of shell-substance; but where they are rendered apparent by abrasion or otherwise, they are seen to be doublea somewhat striking peculiarity. The terminal chamber is often large and projecting. Diameter $\frac{1}{25}$ inch.

Most, if not all, of my specimens (and I have found it in tolerable abundance) are darkcoloured, generally brown, but in some instances quite black; and this is the more remarkable, as the other Foraminifera in the same parcels were beautifully white. This probably arises from the deposit or infiltration of foreign matter in the shell-substance whilst the thickening process is going on. I have noticed in another species, Nonionina turgida, a similar peculiarity with respect to colour, viz. that most of the specimens in some dredgings had the large terminal chamber, sometimes the whole shell, much blackened, whilst the other Foraminifera in the same material presented no unusual colouring. In this case, however, the colouring was probably due to the food of the animal being of a character to produce blackening of the sarcode, which was perceptible through the delicate transparent shell. We have much still to learn respecting the colour of the sarcode in the various species of Foraminifera, which only observations on living specimens can teach.

No. 94. Nonionina stelligera, d'Orb. (Plate XLVIII. fig. 19.)

A small, delicate variety of Nonionina asterizans, F. \& M., sp., having the stellate sutural limbation developed to its fullest extent, with some thickening of the umbilicus. D'Orbigny describes a peculiar elbow-like twist in this sutural thickening, which may be an occasional, but is certainly not an invariable character. This species was obtained by d'Orbigny in sea-sand from Teneriffe, in which he states it was very rare; in the Shetlands it is also very rare; but it has been found in considerable abundance in the Mediterranean, on the Norwegian coast, and in the Arctic seas. Diameter $\frac{1}{70}$ inch. (See d'Orb. For. Canaries, pl. 3. figs. 1 \& 2.)

In the following list will be found named all the species of Foraminifera which have been observed in the examination of Shetland sands; the depth at which they occur, and their comparative scarcity, have been appended so far as practicable.

A single specimen of Truncatulina refulgens, Montfort, sp., was noticed; but it was in a somewhat distorted condition, and is on that ground omitted from the list. 


\title{
Subkingdom PROTOZOA.
}

\author{
Class RHIZOPODA.
}

Order RETICULARIA.

(FORAMINIFERA.)

Suborder IMPERFORATA.

Family MILIOLIDA.

[As indications of the more or less frequent occurrence, in the column for "Frequency" the following symbols are used:- $v$, $r$., very rare; $r_{.,}$rare; $r . r_{.}$, rather rare; $r . c .$, rather common; $c$. common; $v . c$. , very common.]

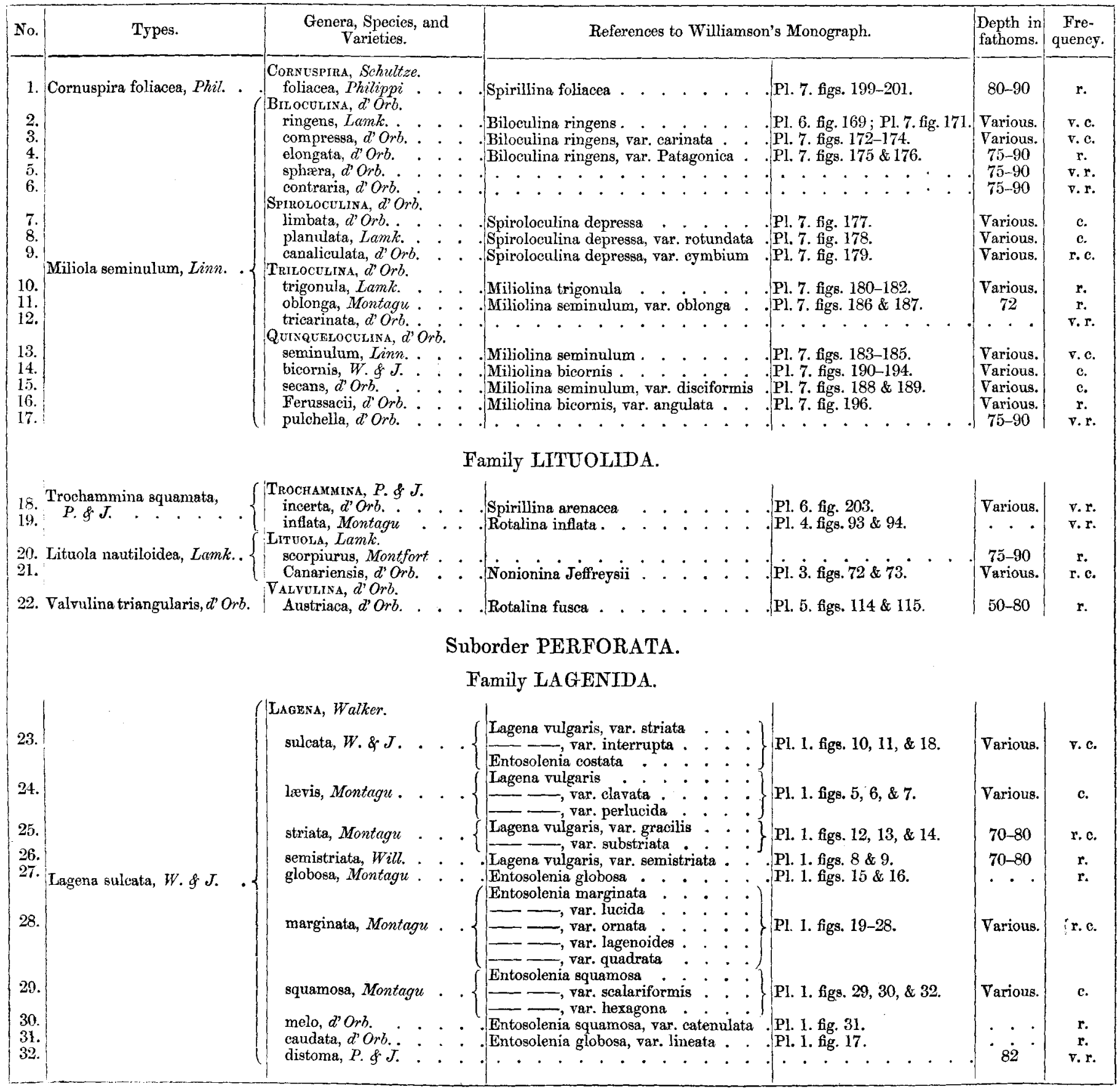


Family LAGENIDA (continued).

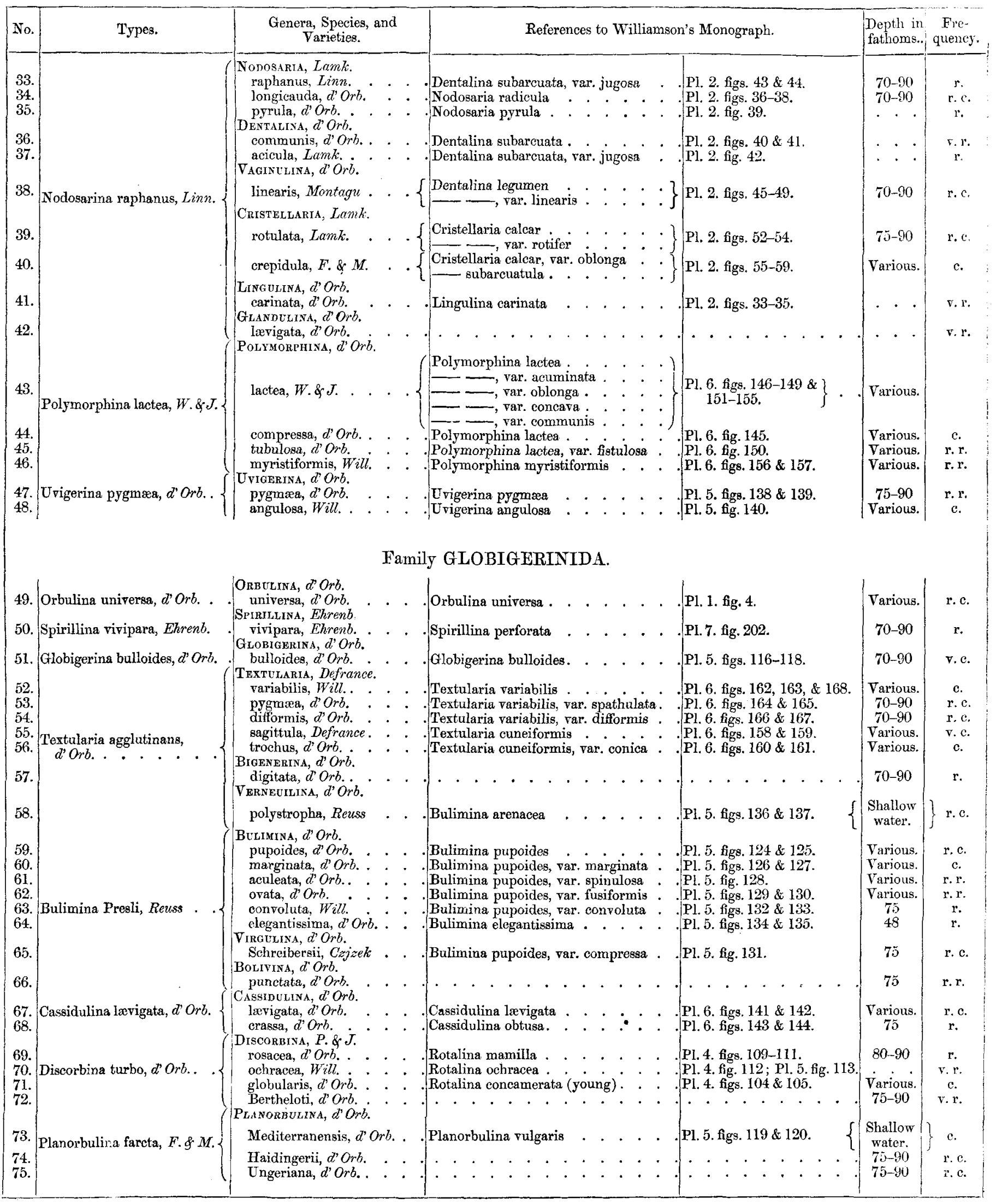


Family GLOBIGERINIDA (continued).

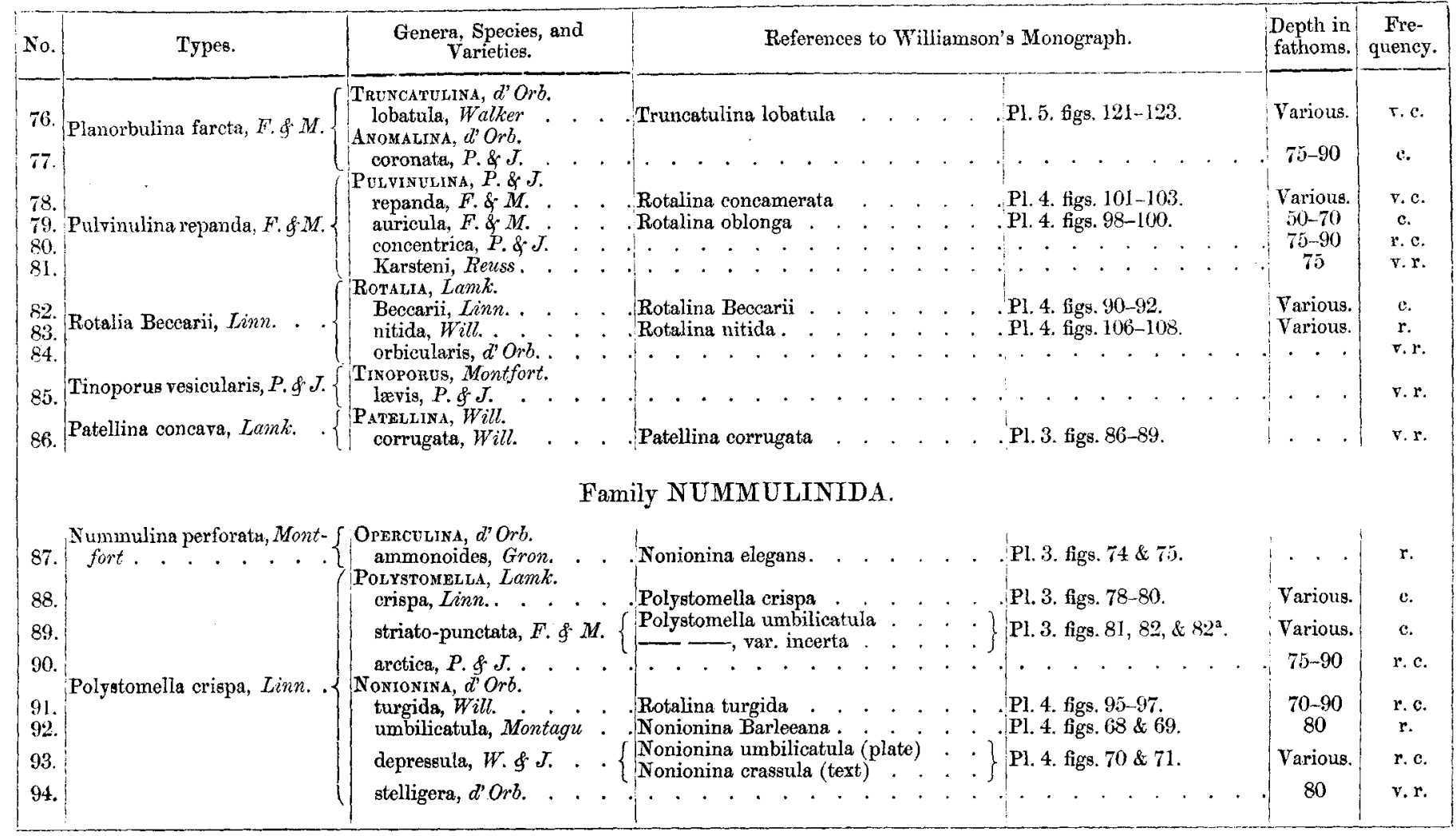

\section{EXPLANATION OF THE PLATE.}

\section{Plate XlVIII.}

Fig. 1. Biloculina sphara, d'Orb., magnified 40 diameters.

$a$, front aspect; $b$, side aspect.

Fig. 2. Biloculina contraria, d'Orb., magnified 25 diams.

$a$, front aspect ; $b$, side aspect.

Fig. 3. Triloculina tricarinata, d'Orb., magnified 40 diams.

$a$, periphero-lateral aspect ; $b$, end aspect.

Fig. 4. Quinqueloculina pulchella, d'Orb., magnified 25 diams.

Fig. 5. Lituola scorpiurus, Montfort, sp., magnified 25 diams.

Fig. 6. Lagena distoma, P. \& J., magnified 75 diams.

Fig. 7. Glandulina lavigata, d'Orb., magnified 45 diams.

$a$, periphero-lateral aspect ; $b$, end aspect.

Fig. 8. Bigenerina digitata, d'Orb., magnified 30 diams.

$a$, periphero-lateral aspect; $b$, diagram showing the arrangement of chambers.

Fig. 9. Bolivina punctata, d'Orb., magnified 85 diams.

$a$, periphero-lateral aspect; $b$, periphero-lateral aspect, marginal view. 
Fig. 10. Discorbina Bertheloti, d'Orb. sp., magnified 90 diams.

$\alpha$, superior lateral aspect; $b$, inferior lateral aspect.

Fig. 11. Planorbulina Haidingerii, d'Orb. sp., magnified 40 diams.

$a$, superior lateral aspect; $b$, inferior lateral aspect; $c$, periphero-lateral aspect.

Fig. 12. Planorbulina Ungeriana, d'Orb. sp., magnified 30 diams.

$a$, superior lateral aspect; $b$, inferior lateral aspect; $c$, periphero-lateral aspect.

Fig. 13. Anomalina coronata, P. \& J., magnified 25 diams.

$a$, superior lateral aspect; $b$, periphero-lateral aspect.

Fig. 14. Pulvinuliná concentrica, P. \&. J., magnified 25 diams.

$a$, superior lateral aspect; $b$, inferior lateral aspect.

Fig. 15. Pulvinulina Karsteni, Reuss, sp., magnified 35 diams.

$a$, superior lateral aspect; $b$, inferior lateral aspect; $c_{z}$ periphero-lateral aspect.

Fig. 16. Rotalia orbicularis, d'Orb., magnified 100 diams.

$a$, superior lateral aspect; $b$, periphero-lateral aspect.

Fig. 17. Tinoporus levis, P. \& J., magnified 50 diams.

Fig. 18. Polystomella arctica, P. \& J., magnified 30 diams.

Fig. 19. Nonionina stelligera, d'Orb., magnified 90 diams.

$a$, superior lateral aspect; $b$, periphero-lateral aspect. 


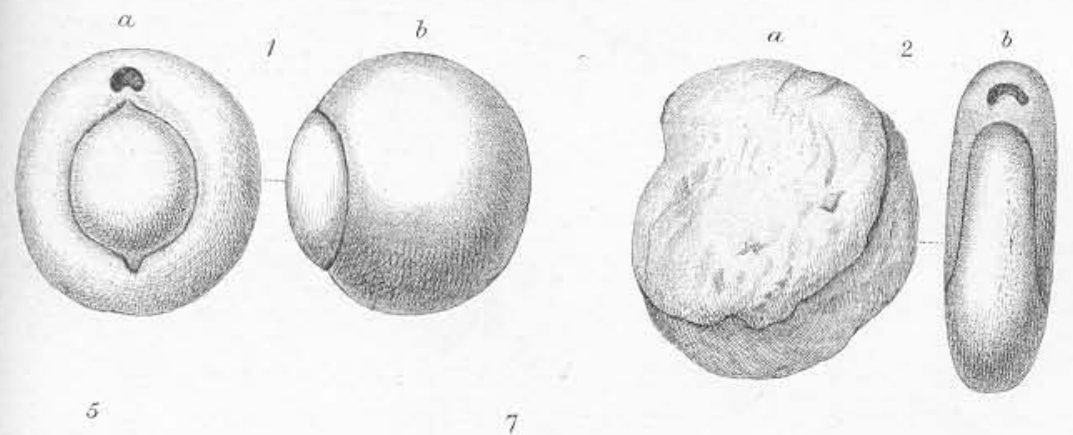

Trans. Iinn SocVor, XXIV PI, 48.
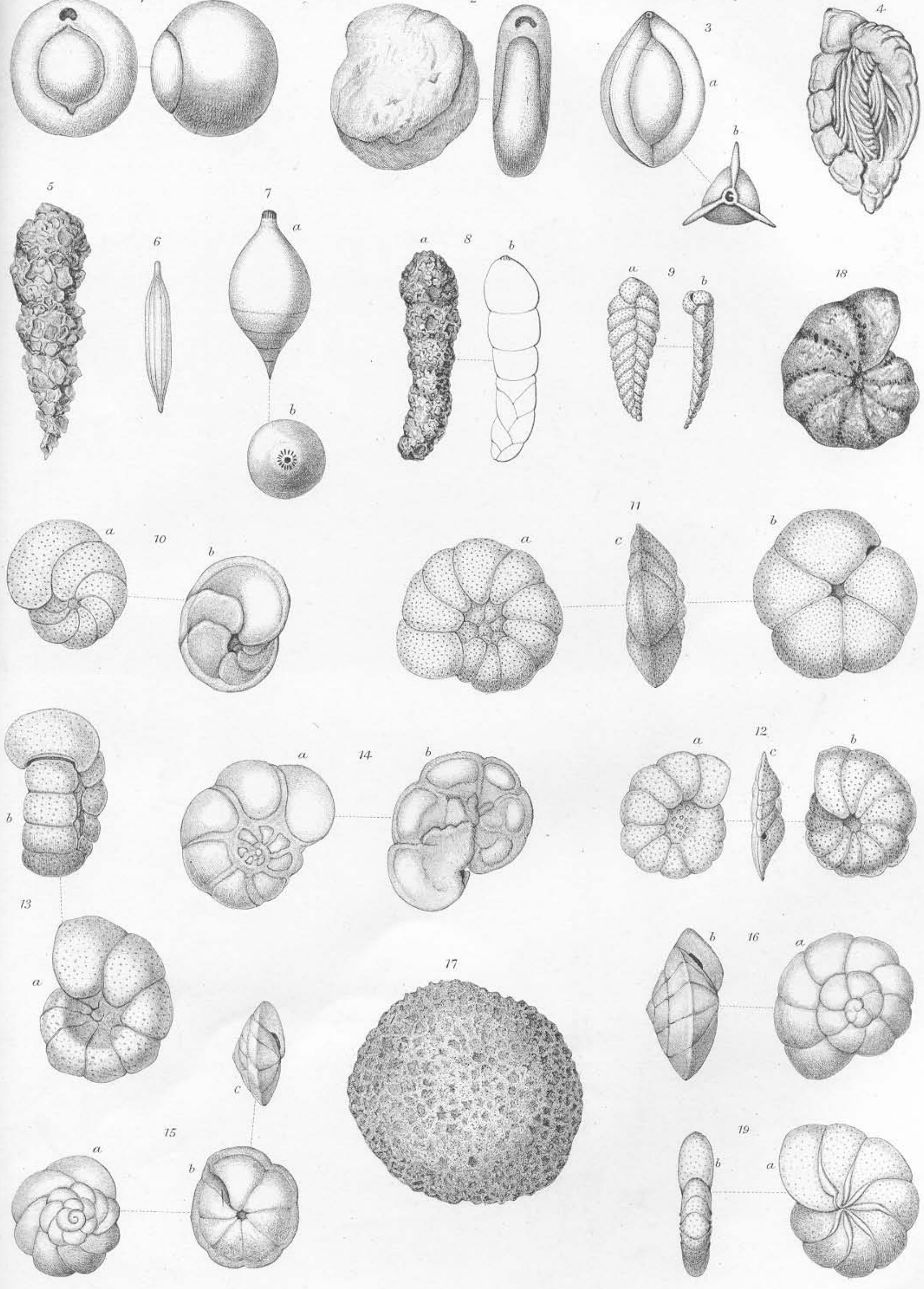